\title{
The Image of the Order Figurative Reconstruction of the Architecture in the Recueil Elementaire d'Architecture by Jean François de Neufforge ${ }^{+}$
}

\author{
Domenico Pastore \\ Department dICAR, Polytechnic of Bari, Architectural Representation-ICAR 17, 70125 Bari, Italy \\ * Correspondence: domenico.pastore@poliba.it; Tel.: +39-340-823-7601 \\ + Presented at the International and Interdisciplinary Conference IMMAGINI? Image and Imagination \\ between Representation, Communication, Education and Psychology, Brixen, Italy, 27-28 November 2017.
}

Published: 24 November 2017

\begin{abstract}
In the Recueil Èlémentaire d'Architecture, J.F. de Neufforge writes a syllabus about all the building styles, analysed according to the formal idea of a classic architecture that can create the identity of the growing middle class of the Eighteen century. Though employing complex geometries which, for their centre,define the position of the archetype elements, such as the base, the peristyle, walled cell and the pediment, Neufforge creates generative processes of the figurative architectures based on the ratio given by the module. In this paper, the possible metric inconsistency between the use of the system of the order - as building algorithm of the architecture in the vertical elements - and the role of the construction of the plan - as a representative and constitutive matrix of the entire building-are investigated. The author questions the value of the order in its practical and aesthetical use.
\end{abstract}

Keywords: architectural orders; scheme; graphical analysis; neoclassicism

\section{Materials and Methods}

Between 1757 and 1780 Monsieur Jean François de Neufforge imagined and realised the Recueil Elementaire d'Architecture. He personally designs and carves eight volumes and two supplements including more than 900 engravings in large format $(24 \times 37 \mathrm{~cm} / 9 \times 13$ inches).

The structure of the Recueil is consistent: each volume consists of twelve chapters with six drawings each. The two supplements are an exception with fourteen and four chapters respectively. The work was positively commented by Neufforge's master [1], Jacque François Blondel, since 1756 [2] when only 24 copies where printed.

Mr de Neufforge lived in the transition period between the late Baroque experimentations and the early figurative idea which will define the "pure" architecture of the late XVIII century [3]. He can be seen "at the same time eclectic and reformist" [4] due to the freedom he applies in composing classical elements in innovative architectural systems, sometimes as divertissements.

In the Recueil, the Author covers the entire range of architectural fields-from entire buildings to interior design, not excluding gardens, squares and funerary monuments, varying typology, ambient and scale in his projects. All these drawings are imagined and original architectures, not survey as it was recurrent for this kind of treaties.The Recueil is organized as an encyclopaedic syllabus, conceived to present entire "Possible Cities" to the general audience. For this reason, the Recueil can be defined as a ground breaking work since after few years during the French Revolution, the architects followed the ideas expressed in Neufforge's treaties, translating Rousseau's political ideology expressed in his masterpiece Du contract social (1762) into architecture. 
In the first half of the eighteen Century, the social structure was being revolutionized, especially in France, where the Middle Class was growing. This group would become the major audience for all the dissertations about architecture at the time. As a matter of fact, J.F. de Neufforge introduces his third volume (Figure 1) edited in 1760 as following: RECUEIL ÉLÉMENTAIRE D'ARCHITECTURE CONTENANT Des Distributions de Bâtimens Bourgeois, Depuis Deux Toise de Face jusquà 24 .

In this way, he clearly shows the recipients of his projects and which collective imaginary his architecture was appealing to. The Recueil's objective is to build the new identity of the dominant class to be, through the research of a new order in architecture and new methods to represent it, which can express the novel social rules.

The significative creative tension to represent the changes in the society, which in France culminated in the French Revolution in 1789, shared among a generation of architects as a social obligation does not appear to be neither unique not isolated in history.

Three centuries earlier in the Florentine Republic, a similar process took place during the Renaissance [5]. Starting from the massive production of treatises in those years, it is possible to highlight the real influence of the drawing on architectural production. The drawing becomes an instrument to pre-figure, to imagine, the space to be and to channel the client's approval.

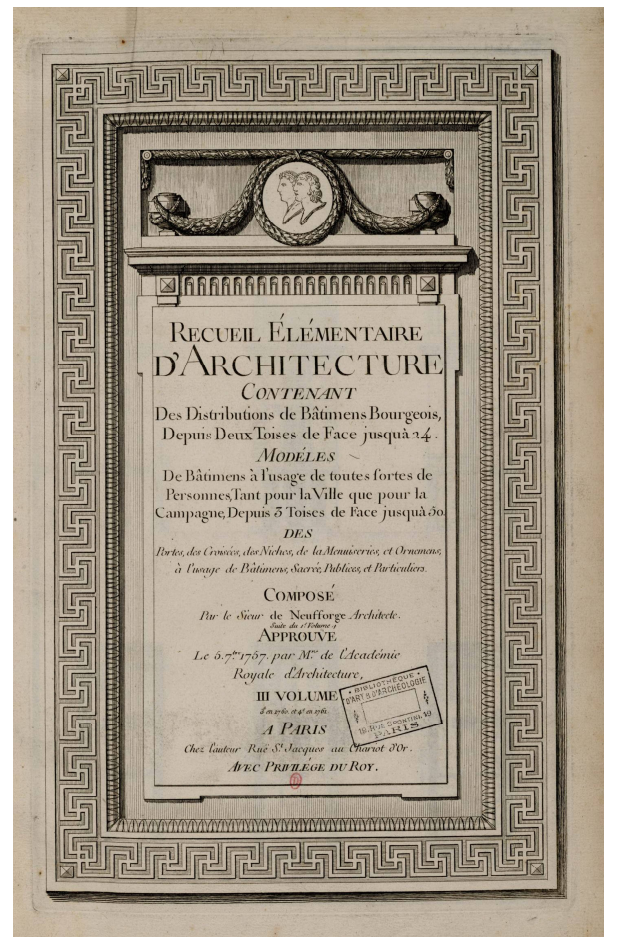

Figure 1. Frontispiece of Volume III.

The pre-figuration of architecture and the application of the architectural order begin to be used as theoretical device to guide the style and represent the character of the building for the new society. This change, compared to the past, is a consequence of the combination of historic cultural and social events such as the discovery of the archaeological ruins of Pompeii and Ercolano (1709 and 1748) which brought the revival of the so called goût grec. Mr. Neufforge followed the goût grec in a preliminary phase of his career [6] when he was a protegee of the main authority of this style at the time, The Earl of Cylus [7]. Furthermore, the rise of a new collective knowledge of the Enlightenment principles, which were translated into architecture founded on the French Rationalism at the end of the 1700s [8], helped the process.

That said, the communicative intent in architectural representation, produced during the classicistic period, is evident and it is specified by a different application of the concept of order compared to the Renaissance. To the freedom of someone who can live with the work of others [9], 
in the "classicism of the period of the Revolution, the emerging Middle Class opposed its image of the Greek temple whose columns perform the duty implicit in their shape. This is the image of a society of free subjects, equals and economically independent" [10].

The whole process of classicist visual reconstruction comes from the well known Renaissance treatises about the architectural order. The visual reconstruction loses its rhetorical aspect, typical in the Roman architecture [11,12], to give space to a new system: order and classical figure as base, peristyle, walled cell and crowning element are re-designed with new criteria which represent the autonomy of the Bourgeois society.

Neufforge's aim is to make the individual identify with the construction. He defines a more complex configuration and organization in his architectures through the combination of elementary shapes (square, circle or triangle). In Neufforge's works, the architectural order determines the right proportion according to the use (Figure 4) and the right style according to the client: "this is the choice of the way of being" [13].

The effort to understand the processes which originated Neufforge's projects has the intent to investigate the dimensional relationship between the plan and elevation. These relationships are governed by the rules of the order which can be followed or manipulated to create the desired global image [14]. Indeed, the architectural order is a functional device to allow an "accessible" design, giving the architect the freedom [15] to create the highest number of images with a single rule. For example, in the study reported in Figure 2 it is interesting to consider whether each drawing is developed according to the ratio of the mimesis [16] or they are linked to a design process which allow the construction of the plan - which finds its meaning in the elevation-according to a logical sequence of signs. The architectures represented in the dissertation appear as a union between archetypal figures and architectural styles modified according to the needs of the time and composed to give shape to a raising society willing to be portrayed.

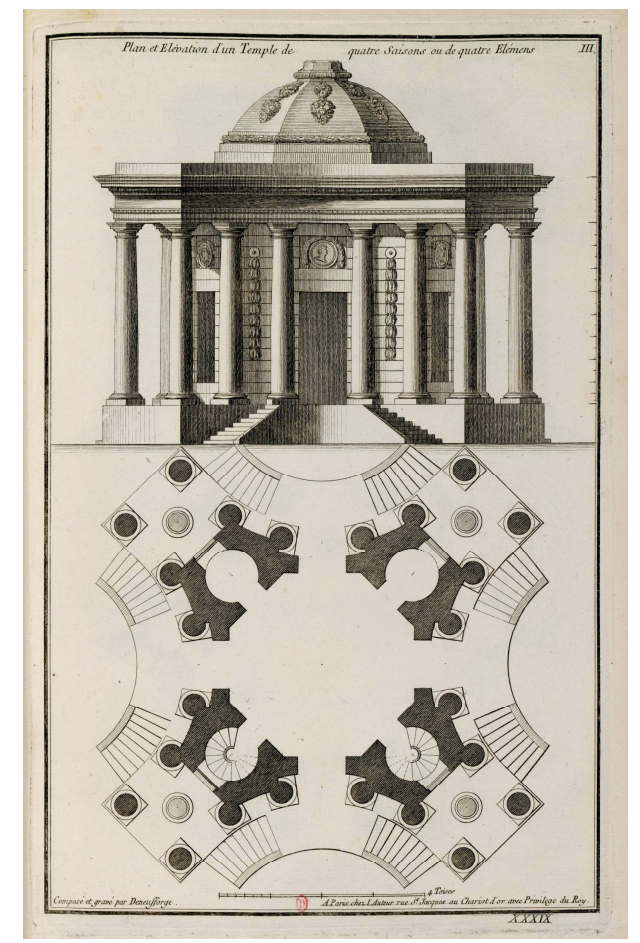

Figure 2. Plan and elevation of a temple of the four seasons and four elements. Supp. I, cap. XXXIX, p. III.

In table n.1 in Chapter 3 Volume I in the Recueil (Figure 3), the five architectural orders are reported and introduced with an author's description which explains the origin and how they belong to be classic languages [17]: 
Model which represents the five architectual orders drawn, in their proportion, according to the ancients' opinion and the modern sentiment with different examples of intercolumn suitable for façades and for internal decorations in public and religious monuments.

Composed by Monsieur de Neufforge, Architect.

These five architectural orders inherited their names from the populations who introduced them; since the height of the columns is based on the proportion of the human body, where the bases and the capitals represent the shoes and the hairstyle and the grooves imitate the draperies of the clothes, generally speaking they have a planning ratio of the parts which increase in relation to the grade of masculinity, to the slimmer and delicate, such as the Tuscanic is fixed to 7 diameters, the Doric to 8 , the Ionic to 9, to Corinthian to 10, the Composite and the Roman to 11, as in the Vesta Temple in Rome and they reduce the dimension of the trunk by one sixth, starting from a third of the height of the column.

Usually all trabeations have four modules, to increase the lightness on the base of solidity more or less in every type of column. According to the origin, the architrave represents the main lintel, the frieze, being smaller, keeps the place of the beams, the pediment emphasizes the strong points, and the struts give shape to the mutules, the medallion and the dentils which give more solidity, prominence and magnificence to the order.

The pedestals and the stylobates have been reduced to a quarter of the column's height and, instead of the pedestals, it is preferred to install a base of two modules in height; the pillar linked to the columns have the size of one module and eight ninth on the bas and of one module and two third at the top such that the proportion of the capitals, the pillars and the columns are all in balance with the trabeations. All the pillar's bases protrude for a fifth of their diameter.

The unusual method chosen by Neufforge to compare the orders reveals the influence of the mentality of his period: the proportions are selected independently by the author for stylistic reasons. As a matter of fact, the Vignola Rule is rarely applied, only to define the number of module per orders.

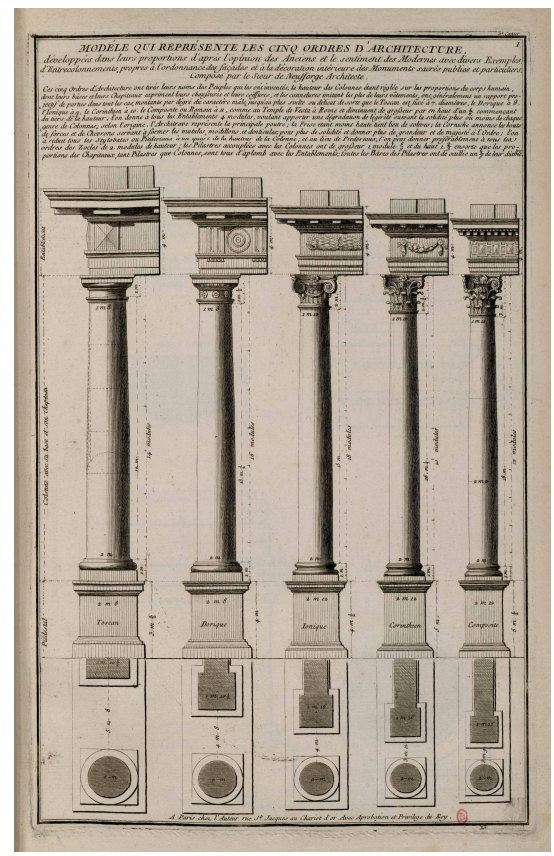

Figure 3. Table of the comparison of the orders. Vol. 1, $3^{\circ}$ cahier, tav. 1, p. 13. 


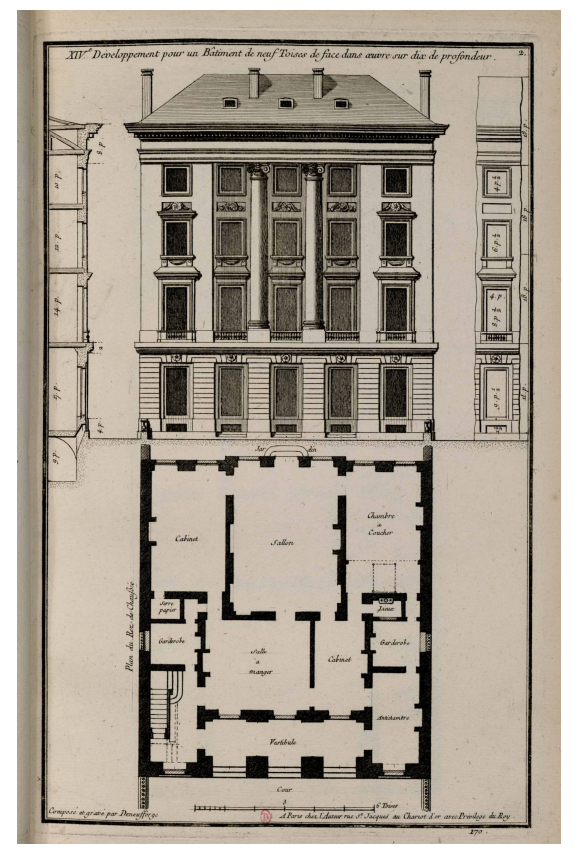

Figure 4. Building $9 \times 10$ toise/17.541 × 19.49 m. Vol. III, cap. 29, tav. 2, p. 170 .

Neufforge creates a drawing in which the pedestals and the columns with base and capitals appear consistently to have the same measure while only the height of the trabeation changes. The expedient to obtain this effect is the application of the same scalar ratio between these objects. The indication in the Vignola Rule which state that the proportional ratio between the three elements: trabeation, column and pedestal, shall be 4:12:3 is by-passed. Neufforge directly assigns the modular value to the single parts. Therefore, the trabeation has a fixed dimension for all the five orders equal to 4 modules, the column is 14 modules for Tuscanic, 16 for the Doric, 18 for the Ionic, 20 for the Corinthian and 22 for the Composite. In particular, the last one has the most significant variation which allows to keep the same scalar ratio among different order equal to 2.5 modules. This represents the real novelty introduced by the author (Figure A1). The module of the architectural order is non-dimensional in the process of designing. During the design phase there is the necessity to assign a real value.

In his flyleaf, Neufforge explains which measure he applies in the following quote: "The French toise consists of 6 feet, one foot consists of 12 inches, and each inch by 12 lines" [18]. With a simple equation, the value in meters of the toise is calculated to be 1949 .

\section{Results}

The application of the order is supported by the use of elementary geometrical figures which implicitly define the architectural composition and demonstrate the individualistic leanings of the time from a visual point of view [19].

Across the whole treatise, the representation used by Jean-François de Neufforge as a medium of the new architectural image are the plan and the elevation of the building which are related with proportional relationship and spatial reciprocal implication dictated by the use of the architectural order. This becomes the device which defines the correspondence of the parts with the whole, the element with the structure, the column with the building and the individual with society (Figure A3). The visual shape is determined by the interdependence existing between two representations of the same object and by reconstructing an unambiguous tri-dimensional image which becomes the geometrical and architectural model. This organisation of the representations is not only shaping the architecture, but also generates the meaning [20] which sets the new imaginary: the founding principle of the PLAN express how the architecture should seize the ground and the expressivity of the façade of the ELEVATION represents its public facies (Figures 5 and 6). 

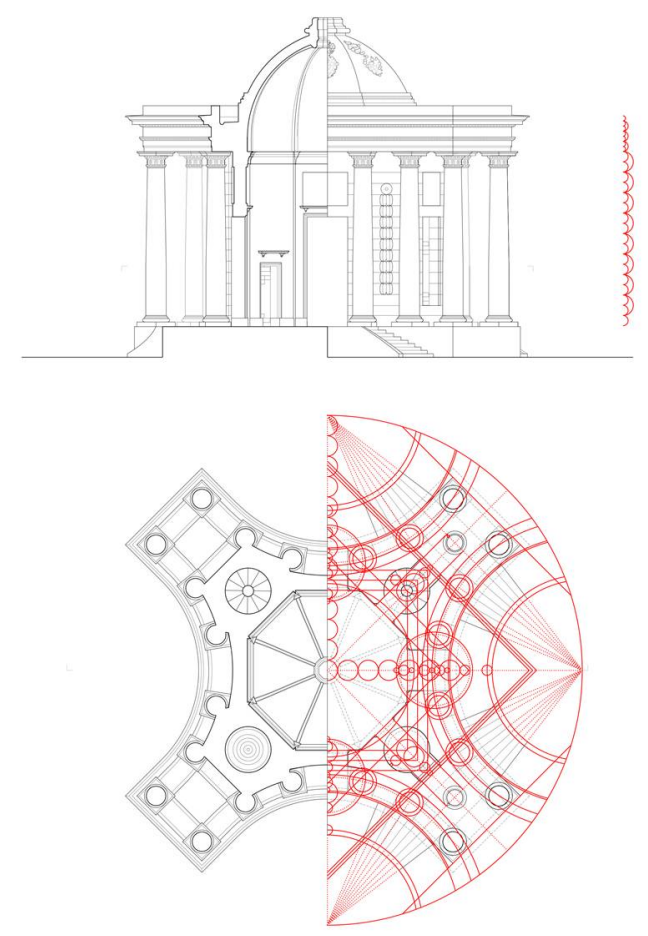

Figure 5. Section/Front and typography/plan with the superposition of the.
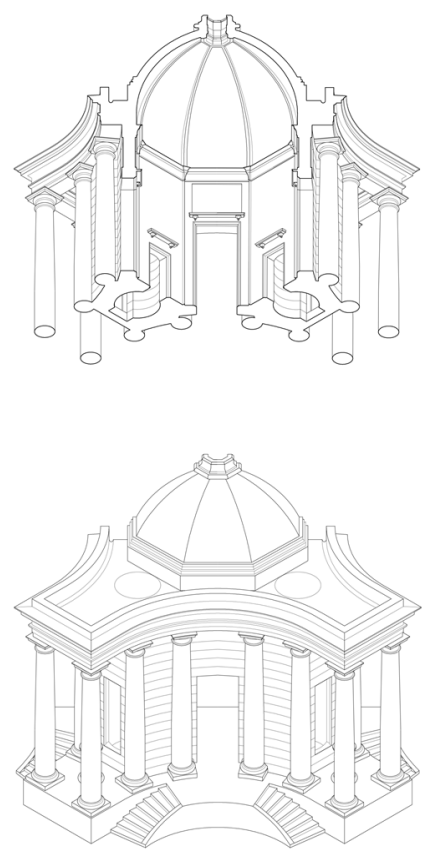

Figure 6. Top and bottom Axonometric cross section.

The image of the buildings in the tables represents possible projects but are unrelated to specific places. For this reason, they are organized in building styles according to the typical classification system of the Recueil at the time.

In this way, the author, by marking the encyclopaedic spirit of his work, creates a device which can expedite comparison of single categories helping the architects to select the more suitable style for the use of the building for a particular project. The author represents different elementary visual variations without reporting the geometrical matrix in a unique form. On the contrary, Jean Nicolas Louis Durand will later explicit the composition rules in some tables of his work Précis des leçons d'architecture données à l'École Royale Polytechnique and in particular in the "Marche à suivre dans la composition d'un projet quelconque" (Figure 7) and "Ensamble d'édificies résultants de la combinaison 
horisontale del leurs parties" [21]. In J.N.L Durand's tables it is adamant the construction process of the planimetric figure of a general building. In this work, the sequence of five plants which initiate from a scheme based on the crossing of two axes, expand with the introduction of grids and elementary figures. These figures stratify defining progressively the walls and the spatiality of the building. On the other hand, in Jean-François de Neufforge's tables representing a series of building for collective and commemorative use, the figure of plan in its formal complexity, often defined by the use of the schematic principle of the interpenetration [22], is the unique representation that needs a geometrical interpretation as formal de-codification to support the project [23]. The interpretation begins from the determination of the measuring module and takes to the definition of the latent scheme to be replicated or modified.

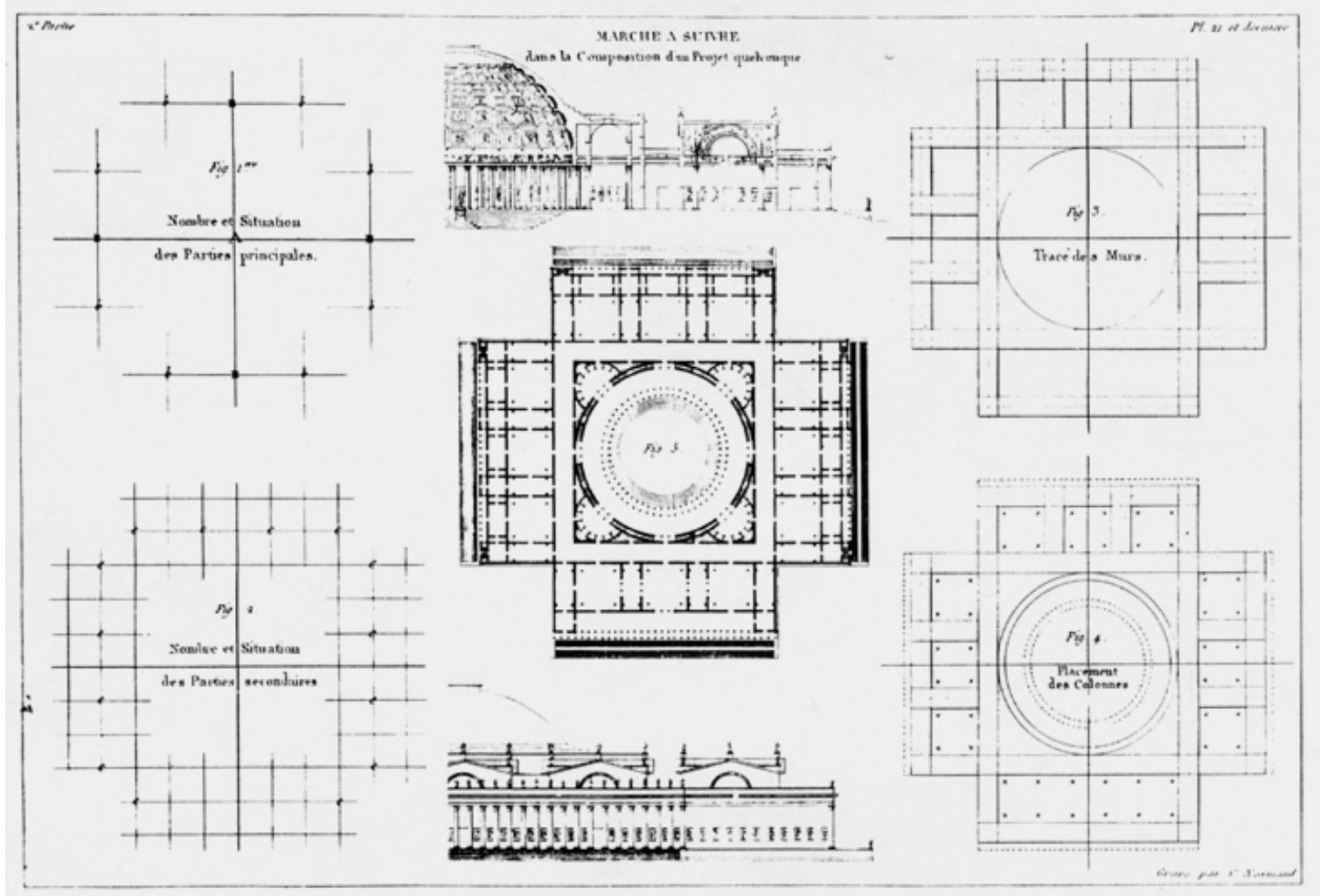

Figure 7. Table from Marche à suivre dans la composition d'un projet quelconque.

This architectural representation is identified by a particular orthogonal projection which impress on the paper a portion of the building located below a certain height from the section view. This needs a clear tri-dimensional visualisation of the building in the architect's mind and at the same time the possibility to build on an undifferentiated surface [24]. This clear visualisation of the architectural shape-which do not allow a realistic representation, but describes the organization, the spatiality and the internal structure-is the result of a design process in which the generative figurative actions remains in latent form, becoming the genetic code of the building, to be included inside the scheme [25]. Defining the metric rule based on the varied use of the rules of the order [26] and understanding the geometrical components based on the elementary figures, helps to capture the trend in the sketching from the first half of the XVIII century which aimed to a decomposition of the forces which joint the space and the elements, breaking the centrifugal tradition of the past. This process leads to the top of the architectural production during the Enlightnment [27].

\section{Discussion}

The concept of the scheme contains the principles through which the architectural discipline is defined theoretically and didactically [28]. For this reason, it is possible to find in the exempla 
reported in the Recueil the graphical representation of the architectural philosophy typical of the Bourgeoise society.

The definition of a centre, from which the elementary figure of the composition is generated, is the first creative act in the sketching which link the Euclidian geometry with the proportions given by the module of the order chosen to define the elevation of the building.

The graphical analysis [29] applied to some case studies defines a constructive process of the shape obtained through the determination of the central core and proportionated on a simple geometry, which is defined on the double module of the diameter of the column in the lower scape and progressively unveils the concatenation of the figures within the spatial relations, redefining the parts which compose the architectural organism and made it possible to represent in a cartesian space [30].

The sequential identification of the archetypal figures, which compose the buildings, begins form the definition of the centrality of the walled cell-intended as a vacuum space in which the other part relates in proportion - then the individuation of the base on which the construction is elevated and finally determining the trajectory of the dotted border of the building that is the peristyle (Figure A2). The profile of the crowning element, which defines the upper limit of the roof/cover, is determined by the construction of the elevation by the rule of the selected order. The gradual growing of the architectural shape through the stratification of geometries and proportional relationships explains how the construction of complex elements in a composition, and the following attribution of architectural meaning to those elements, brings to the disappearance of the initial signs, determining a unique image fixed in the bi-dimensional space. This representative process clearly hybridise architectural models from which the elements are progressively deduced. These elements blend in the elaboration of the plan, losing their original and well known individuality to become part of the whole (Figure A4).

\section{Conclusions}

In the Recueil Èlémentaire d'Architecture, it is important to note the beginning of a shift in the concept of mimesis. From the imitation of the ancient ideal models as a base for a new architecture, the mimesis evolves into an application of the imitation of the character of classic buildings with Quatremère de Quincy. The attention will move from the formal models to the subjective contents, to be finally replaced with the principle of the Convenence e Économie [31] by Jean Nicolas Louis Durand.

Conflicts of Interest: The authors declare no conflict of interest. 


\section{Appendix A}

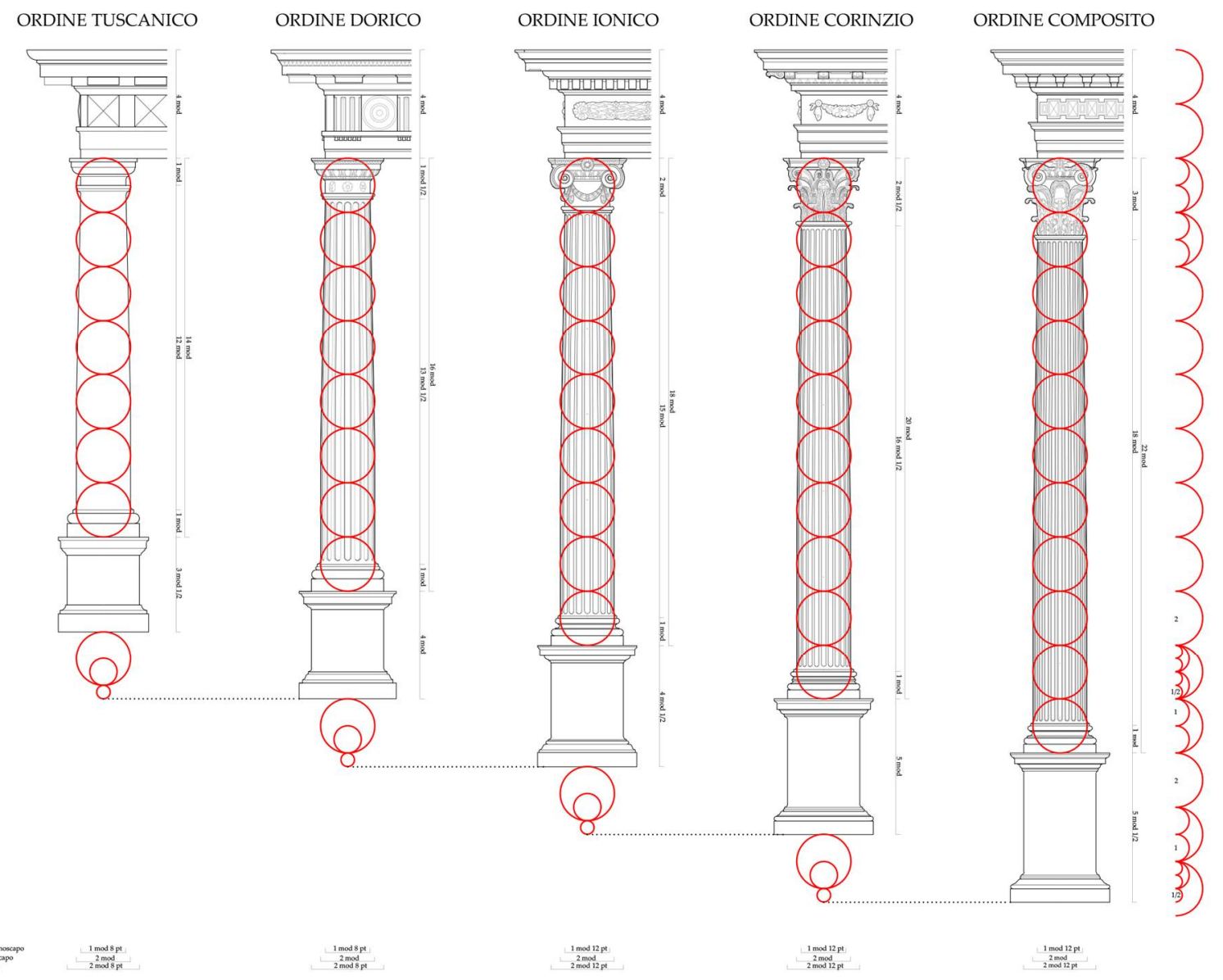

Figure A1. Drawing of the comparison between the architectural orders with the analysis of the reduction ration. 


\section{Appendix B}
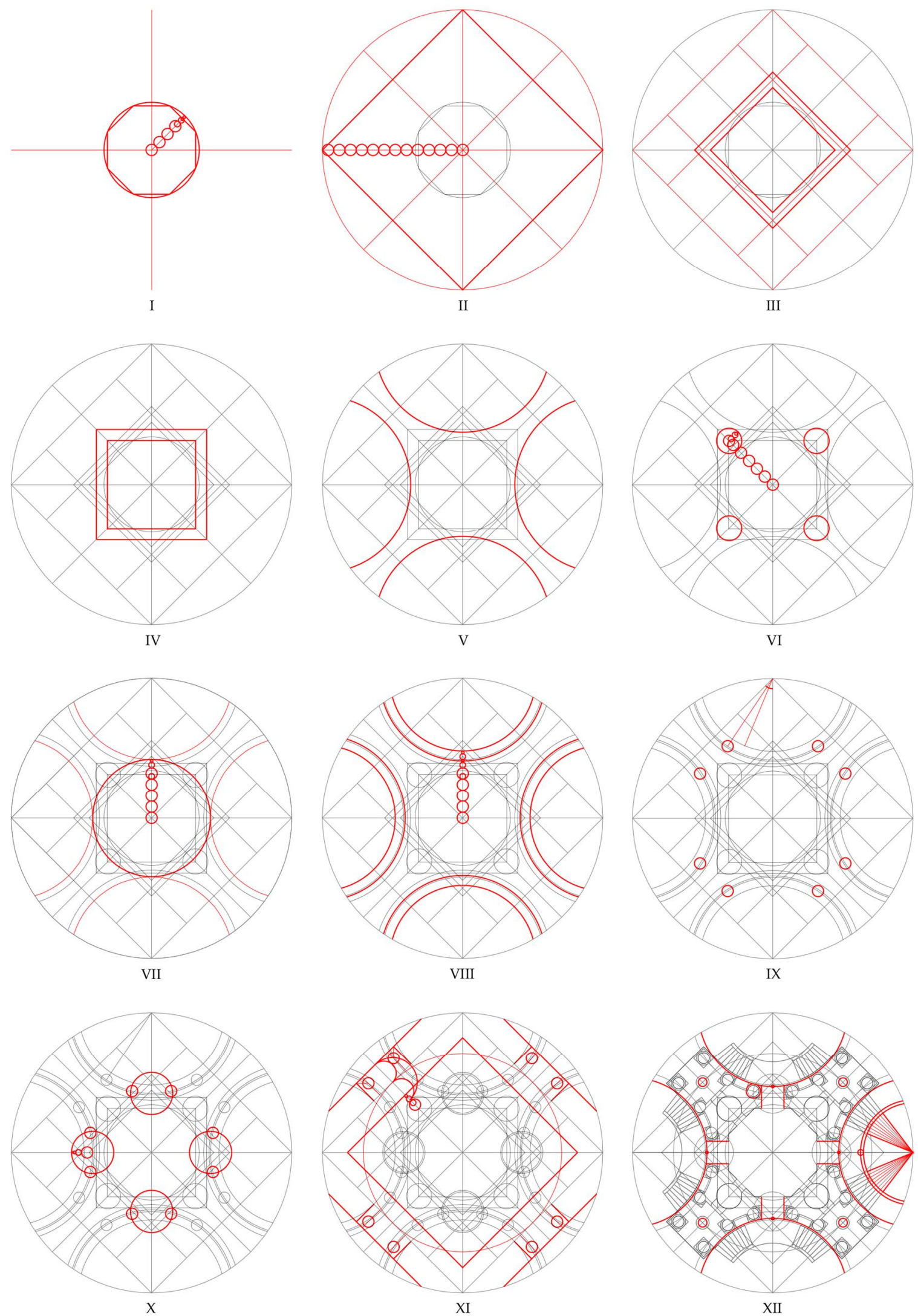

Figure A2. Geometrical proportional scheme to create the plan de-composed in 12 essential passages: starting from the central octagon, the wall cell, the position of columns in the peristyle, the limit of the base, the openings and stairway are defined. 


\section{Appendix C}

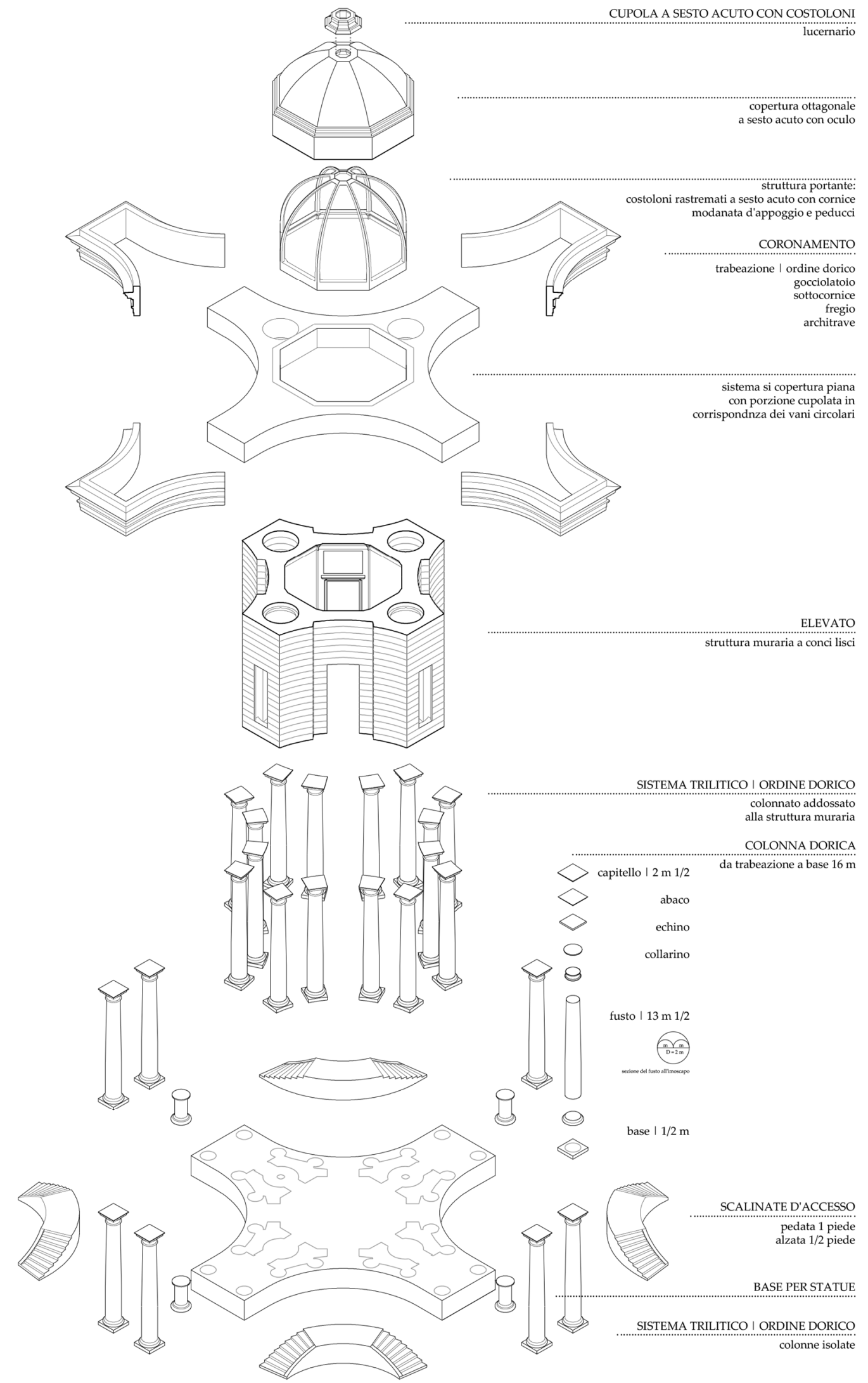

Figure A3. Axonometric exploded view of the temple analysed. 


\section{Appendix D}
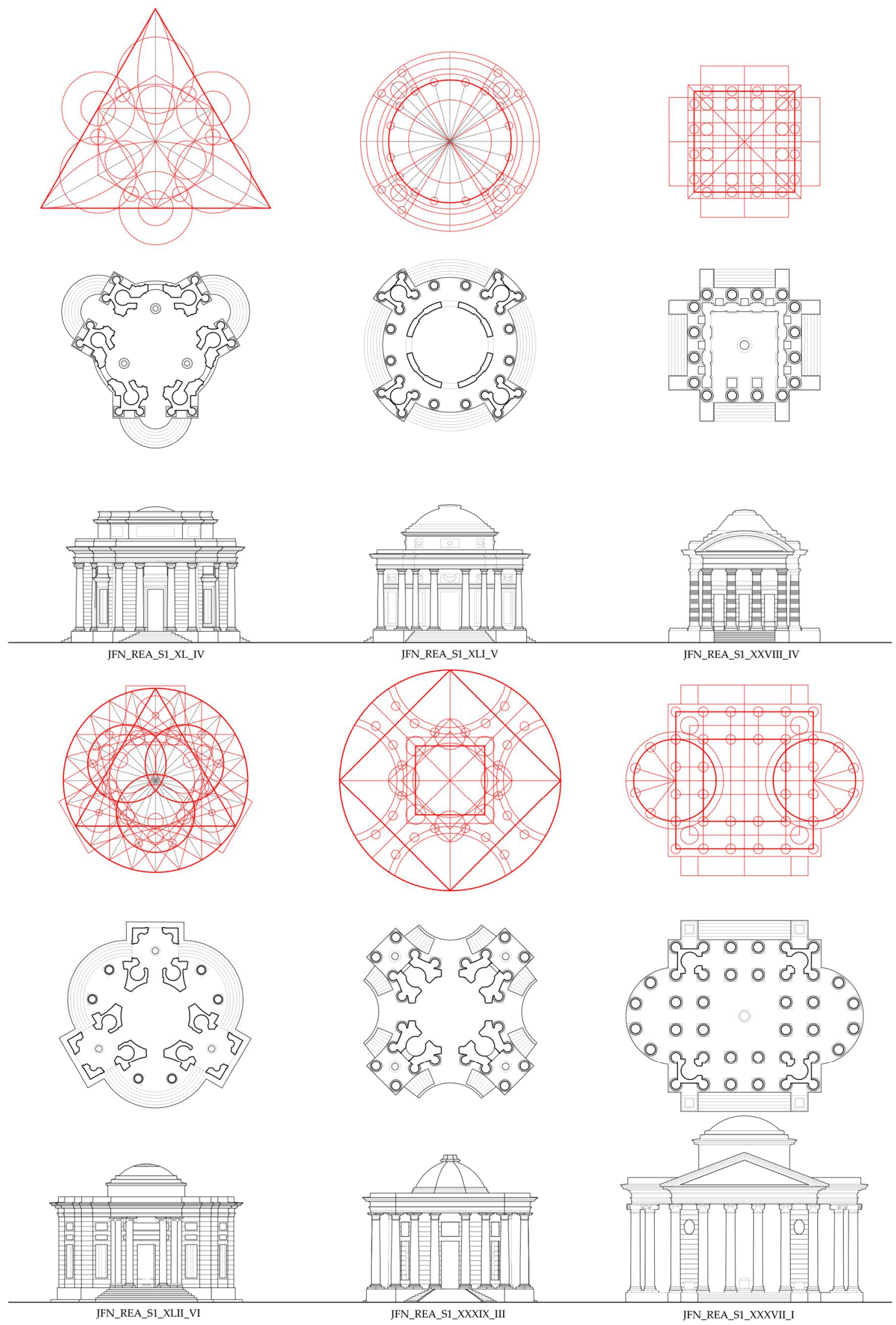

Figure A4. Partial taxonomy of independent buildings for a geometrical-formal matrix. 


\section{References}

1. Kruft, H.-W. L'estetica architettonica relativistica, l'Illuminismo e l'architettura rivoluzionaria. In Storia Delle Teorie Architettoniche-Da Vitruvio al Settecento, 2nd ed.; Laterza, Ed.; Poligrafo Dehoniano: Bari, Italy, 2004; p. 197, ISBN 88-420-5804-1.

2. Mémoires pour l'Histoire des sciences et beaux-arts, juin 1756, art. 65, p. 1524.

3. Kauffmann, E. Da Lemercier a Soufflot. In L'architettura Dell'illuminismo, 2nd ed.; Giulio Einaudi Ed.; Industrie Grafiche C. Zeppegno: Torino, Italy, 1971; pp. 149-174.

4. Kauffmann, E. Gli architetti della Rivoluzione Francese. La generazione del 1730. In L'architettura Dell'illuminismo, 2nd ed.; Giulio Einaudi Ed.; Industrie Grafiche C. Zeppegno: Torino, Italy, 1971, p. 176.

5. Thoenes, C. "Sostegno e adornamento". Gli ordini architettonici come simbolo sociale (1972). In Sostegno e Adornamento. Saggi Sull'architettura del Rinascimento: Disegni, Ordini, Magnificenza, 1st ed.; Electa, Ed.; Elmond Spa: Martellago, Venezia, Italy, 1998; p. 69, ISBN 88-435-6112-X.

6. Middleton, R.; Watkin, D. Architettura, La tradizione razionalista in Francia. In Architettura Ottocento, 2nd ed.; Electa, Ed.; Elmond Spa: Martellago, Venezia, Italy, 1998; pp. 65-69, ISBN 88-435-2465-8.

7. Due benefattori dei giovani artisti del XVIII secolo-Il conte di Cylus. In Benefattori Dell'umanità Ossia Vite e Ritratti Degli Uomini Utili, 1st ed.; Luigi Ducci e Comp.; Tipografia Le Monnier: Firenze, Italy, 1845; Volume 3, p. 431.

8. Middleton, R.; Watkin, D., Architettura Ottocento, 2nd ed.; Electa, Ed.; Elmond Spa: Martellago, Venezia, Italy, 1998; ISBN 88-435-2465-8.

9. Thoenes, C. "Sostegno e adornamento". Gli ordini architettonici come simbolo sociale (1972). In Sostegno e Adornamento. Saggi Sull'architettura del Rinascimento: Disegni, Ordini, Magnificenza, 1st ed.; Electa, Ed.; Elmond Spa: Martellago, Venezia, Italy, 1998; p. 69, ISBN 88-435-6112-X.

10. Thoenes, C. "Sostegno e adornamento". Gli ordini architettonici come simbolo sociale (1972). In Sostegno e Adornamento. Saggi Sull'architettura del Rinascimento: Disegni, Ordini, Magnificenza, 1st ed.; Electa, Ed.; Elmond Spa: Martellago, Venezia, Italy, 1998; p. 73, ISBN 88-435-6112-X.

11. Finoli A. M., Grassi L. Antonio Averlino detto il Filarete. Trattato di architettura. Classici italiani di scienze, tecniche e arti. Trattati di architettura. Collana a cura di Renato Bonelli e Paolo Portoghesi, vol 2; Polifilo editore, 1st ed., Milano, Italia , 1972, p. 214.

12. Emil Kauffmann, Il sistema architettonico del Rinascimento e l'architettura barocca. In L'architettura Dell'illuminismo, 2nd ed.; Giulio, E., Ed.; Industrie Grafiche C. Zeppegno: Torino, Italy, 1971, pp. $93-109$.

13. Summerson, J. Elementi essenziali del classicismo. In Il Linguaggio Classico Dell'architettura. Dal Rinascimento ai Maestri Contemporanei, 11th ed.; Giulio Einaudi editore s.p.a. Torino; Estroprint: Belvedere di Tezze sul Brenta, Vicenza, Italy, 2010; p. 13, ISBN 978-88-06-15452-3.

14. Summerson, J. Elementi essenziali del classicismo. In Il Linguaggio Classico Dell'architettura. Dal Rinascimento ai Maestri Contemporanei, 11th ed.; Giulio Einaudi editore s.p.a. Torino; Estroprint: Belvedere di Tezze sul Brenta, Vicenza, Italy, 2010; p. 13, ISBN 978-88-06-15452-3.

15. Thoenes, C. La "Regola delli cinque ordini" del Vignola. In Sostegno e Adornamento. Saggi Sull'architettura del Rinascimento: Disegni, Ordini, Magnificenza, 1st ed.; Electa Ed.; Elmond Spa: Martellago, Venezia, Italy, 1998; pp. 81-82, 88-435-6112-X.

16. Ugo, V. Fondamenti della Rappresentazione Architettonica, 2nd ed.; Società editrice Esculapio, Digital Print: Segrate, Italy, 2014; p. 18, ISBN 9788874887491b.

17. Summerson, J. Elementi essenziali del classicismo. In Il Linguaggio Classico Dell'architettura. Dal Rinascimento ai Maestri Contemporanei, 11th ed.; Giulio Einaudi editore s.p.a. Torino; Estroprint: Belvedere di Tezze sul Brenta, Vicenza, Italy, 2010; p. 4, ISBN 978-88-06-15452-3.

18. Szambien, W. Construire pour toute personne le toisé de l'architecture. In Symétrie. Goût. Caractère. Théorie et Terminologie de L'architecture à L'âge Classique. 1500-1800; Picard: Paris, France, 1986; p. 30.

19. Kauffmann, E. Gli architetti della Rivoluzione Francese. La generazione del 1760. Nuovi modi di comporre. In L'architettura Dell'illuminismo, 2nd ed.; Giulio, E., Ed.; Industrie Grafiche C. Zeppegno: Torino, Italy, 1971, p. 234.

20. Ugo, V. Fondamenti della Rappresentazione Architettonica, 2nd ed.; Società editrice Esculapio, Digital Print: Segrate, Italy, 2014; p. 75, ISBN 9788874887491b.

21. Durand, J.N.L. Précis des leçons d'architecture données à l'École Royale Polytechnique; Paris, France, 1808; Volume II, tavv. 21 and 195. 
22. Kauffmann, E. Gli architetti della Rivoluzione Francese. La generazione del 1760. Nuovi modi di comporre. In L'architettura Dell'illuminismo, 2nd ed.; Giulio, E., Ed.; Industrie Grafiche C. Zeppegno: Torino, Italy, 1971; p. 235.

23. Kauffmann, E. Gli architetti della Rivoluzione Francese. La generazione del 1760. Nuovi modi di comporre. In L'architettura Dell'illuminismo, 2nd ed.; Giulio, E., Ed.; Industrie Grafiche C. Zeppegno: Torino, Italy, 1971; p. 232.

24. Ackerman, J.S. Architettura e Disegno. La Rappresentazione da Vitruvio a Ghery; Mondadori Electa: Milano, Italy, 2003; ISBN 88-370-2058-9.

25. Ugo, V. Skhêma, U.V. X-Y Dimensioni del Disegno n.3; Officina Edizioni: Roma, Italy, 1987; p. 23.

26. Summerson, J. Elementi essenziali del classicismo. In Il Linguaggio Classico Dell'architettura. Dal Rinascimento ai Maestri Contemporanei, 11th ed.; Giulio Einaudi editore s.p.a. Torino; Estroprint: Belvedere di Tezze sul Brenta, Vicenza, Italy, 2010; p. 15, ISBN 978-88-06-15452-3.

27. Kauffmann, E. Da Lemercier a Soufflot. In L'architettura Dell'illuminismo, 2nd ed.; Giulio Einaudi Ed.; Industrie Grafiche C. Zeppegno: Torino, Italy, 1971; p. 168.

28. Ugo, V. Skhêma, U.V. X-Y Dimensioni del Disegno n.3; Officina Edizioni: Roma, Italy, 1987; p. 30.

29. The potential expressed by the digital tools allows the relation between the representation tool's functional precision and the order rules, Read as the architectural image creation algorithm through a proportional metric system.

30. Ugo, V. Una "Archeologia", c. Elemento come "parte". In I Luoghi di Dedalo. Elementi Teorici Dell'architettura, 1st ed.; Edizioni Dedalo; Dedalo Litostampa: Bari, Italy, 1991; p. 129, ISBN 88-220-6110-1.

31. De Solà Morales, I. Archeologia del Moderno, da Durand a Le Corbusier; 1st ed.;Umberto Allemandi \& Co; Stampatre: Torino, Italy, 2005; p. 31, ISBN 88-422-1126-5.

(C) 2017 by the authors. Licensee MDPI, Basel, Switzerland. This article is an open access article distributed under the terms and conditions of the Creative Commons Attribution (CC BY) license (http://creativecommons.org/licenses/by/4.0/). 